\section{Ida Saidah ${ }^{1}$}

\title{
Pelibatan Orang Tua melalui Kegiatan Ngamen bareng di TK Nurul Amanah Cianjur
}

\begin{abstract}
Abstrak
Penelitian bertujuan meningkatkan perhatian orang tua, sekolah, dan lingkungan terhadap perkembangan anak, melalui kegiatan ngamen bareng diharapkan antara pendidikan dirumah dan pendidikan di TK tidak terputus, Jenis penelitian yang dipergunakan adalah penelitian dengan metode survey. Survey pelibatan orang tua dalam kegiatan ngamen bareng dilakukan terhadap orang tua murid dan lingkungan, terhadap perencanaan program kegiatan ngamen bareng itu sendiri dan perkembangan anak di TK Nurul Amanah yang secara langsung terdampak oleh kegiatan ngamen bareng. Jenis data dan analisis menggunakan penelitian analisis data kualitatif (deskriptif), yaitu data dalam bentuk kata, kalimat, dan gambar. Metode penelitian dengan tehnik observasi, wawancara, dan dokumentasi. Hasil penelitian menunjukkan keterlibatan orang tua murid berada pada tingkat yang baik, keluarga secara aktif terlibat secara langsung, merupakan program unggulan TK Nurul Amanah, disusun secara sistematis, berorientasi pada perkembangan aspek seni dan aspek perkembangan fisik motorik anak.
\end{abstract}

Kata kunci : ngamen bareng, keterlibatan sekolah dan orang tua murid, aspek perkembangan seni dan fisik motorik

\begin{abstract}
:
The aim of the reseaecrh is which increases the attention of parents, schools, and the environment towards the development of children, through joint raising, home education, and kindergarten education. not disturbed, singing activities are oriented towards aspects of developing children's art and motorbikes. The type of research used is survey research methods. The parent involvement survey in the singing group activities was carried out on parents \& the environment, on the planning of the activities of the joint singing program and the development of children at TK Nurul Amanah which was directly influenced by the activities of singing together. The type of data and analysis uses qualitative data analysis (descriptive) research. Research method with observation, interview, and documentation techniques. The survey results show that the involvement and attention of parents at a good level, the families directly involved, are the superior programs of TK Nurul Amanah, arranged systematically, oriented to the development of senior aspects and aspects of children's motor development.
\end{abstract}

Keywords: singing together, school and parents of students involved, sartistic and motoric aspect development

\footnotetext{
${ }^{1}$ Pengawas Taman Kanak-Kanak, Dinas Pendidikan Kabupaten Cianjur

Email : idasaidahsaidah@yahoo.co.id
} 


\section{PENDAHULUAN}

Program PAUD adalah pendidikan yang dapat mengembangkan potensi anak melalui stimulasi sejak dini. Stimulasi pada program PAUD merupakan bagian yang sangat penting. Apabila merujuk pada pendapat Morisson (1988), pendidikan anak usia dini ialah pendidikan yang ditujukan kepada anak dari usia 0 sampai dengan 8 tahun (Morisson, 1988: 3). Pentingnya masa awal anak-anak harus memperoleh perhatian lebih dari orang tua, sekolah, dan lingkungan. PAUD yang berkualitas tinggi akan terwujud dengan dukungan yang berkualitas tinggi pula, dukungan yang berkualitas tinggi ditandai dengan adanya keterlibatan secara aktif dari 3 komponen pendidikan yaitu orang tua murid, lembaga PAUD dan lingkungan masyarakat . Selama ini pun orangtua banyak terlibat pada kegiatan lembaga PAUD, namun hanya terlibat aktif pada saat anaknya mendapat masalah, misalnya ketika bermasalah dirumah atau diluar rumah.

Pada umumnya orang tua murid di lembaga PAUD sering banyak terlibat bersama anak dalam masalah pembelajaran atau masalah administrasi lembaga PAUD. Banyak ditemukan keadaan dimana terputusnya proses pendidikan antara dirumah dan disekolah tidak adanya konsistensi keduanya dalam tujuan pembelajaran. Tidak sedikit kita temukan orang tua dan pendidik dalam hal ini guru di sekolah menjadikan anak sebagai obyek bukan sebagai subyek, sehingga setiap kegiatan di sekolah yang diberikan kepada anak orientasinya adalah sekolah atau orang tua anak . Salah satu contohnya adalah kemampuan anak terhadap baca tulis hitung di TK, pada program tersebut orang tua dan sekolah menempatkan anak sebagai obyek, yang akan terjadi adalah bila anaknya keluar dari TK belum bisa baca tulis hitung sesuai harapan, maka anak akan ditekan untuk ikut les- les baca tambahan di luar program lembaga TK nya atau orang tua menarik anak nya dari lembaga TK semula untuk di daftarkan di TK yang menurut nya dapat membuat anak nya cepat mampu menbaca menulis dan berhitung sesuai harapan mereka. Contoh lain dari terputusnya proses pendidikan antara rumah dan sekolah yaitu hal-hal yang telah baik dilakukan oleh lembaga TK tidak secara konsisten dilaksanakan oleh orang tua dirumah, misalnya di TK anak telah terbiasa dilatih secara mandiri oleh guru untk melaksanakan 2 tugas yaitu menyimpan sepatu dan tas pada tempatnya, manun ketika sampai dirumah, 2 tugas menyimpan tas dan sepatu anak dilakukan oleh orang tua atau pembantu rumah tangga, pendidikan di lembaga TK yang betujuan untuk kemandirian anak dengan melakukan 2 tugas tersebut diatas nampaknya terputus dan tidak secara konsisten dilaksanakan oleh orang tua. Contoh diatas menunjukan bahwa program lembaga TK tidak dikomunikasikan dengan baik, jika demikian nampaknya focus 2 tugas yaitu menyimpan tas dan sepatu anak bukan pada peningkatan perkembangan kemandirian yang berpusat pada anak melaikan untuk kepentingan program sekolah saja .

Dari beberapa contoh diatas terputusnya program pendidikn antara sekolah dan program pendidikan di rumah dikarenakan; (1) kegiatan pelibatan orang tua di lembaga PAUD tidak dikomunikasikan dengan baik antara guru dan orang tua murid,(2) faktor keterbatasan dan ketersedian waktu kegiatan di lembaga PAUD. National Association Early Young Children (NAEYC) sebagai salah satu lembaga yang berperan dalam program pendidikan anak usia dini, menerapkan quality control dalam penjagaan mutu PAUD dengan pertumbuhan dan perkembangan anak usia lahir sampai dengan 8 tahun sebagai acuan dasar, mengatur jam pertemuan di lembaga PAUD dapat diselenggarakan mulai dari setengah hari maupun sehari penuh baik di rumah atau di institusi PAUD (Carol Seefelt \& Nita Barbour, 1998 ; 13, dikutip dari buku pengelolaan kegiatan pengembangan PAUD 4407/modul 1-12.UT ). (3) faktor tujuan program kegiatan lembaga PAUD itu sendiri, dari contoh - contoh diatas, nampaknya lembaga 
PAUD membuat program kegiatan dengan pelibatan orang tua namun hanya berorientasi pada kepentingan lembaga saja

Aspek yang harus ada dalam program-program yang melibatkan orang tua dan mendukung suksesnya program pelibatan orang tua murid di PAUD antara lain: (1) aspek program kegiatan kerjasama yang dirancang oleh lembaga TK hendaknya dapat digunakan untuk semua anak-anak dan dapat dipergunakan juga untuk keluarga mereka (Anita Yus, 2011: 49). (2) program kegiatan pelibatan orang tua dirancang untuk membuat aktivitas lebih berarti bagi orang tua dan dirasakan manfaanya oleh orang tua bagi kehidupan perkembangan anak-anak. (3) program kegiatan pelibatan orang tua di TK secara penuh berdampak positif bagi sekolah, anak-anak dan orang tua. (4) program kegiatan pelibatan orang tua murid secara langsung maupun tidak langsung mendatangkan keuntungan terhadap program TK pada masa mendatang.

Morrison (1988:321) tentang keterlibatan orang tua dalam program kegiatan di PAUD, sebetulnya merupakan proses membantu orang tua, dan membantu saudara, proses bantuan yang terjadi; (1) kerjasama antara orangtua dengan guru adalah saling tolong menolong dalam komunitas. (2) merupakan proses yang berkembang melampaui batasan waktu melalui perencanaan dan usaha dari setiap anggota tim. (3) proses dimana orangtua dan guru dalam bekerja , belajar, dan berpartisipasi dalam membuat keputusan bersama. (4) keterlibatan orangtua dalam proses pendidikan di lembaga TK merupakan sebuah proses yang terus berkembang berupa kerjasama dan berbagi pendapat dalam membuat keputusan terhadap kegiatan pendidikan. (5) dalam pelibatan orangtua, kesiapan dari setiap individu orang tua murid yang terlibat didalamnya menjadi hal yang utama. Lembaga TK dan guru harus memberikan kesempatan bagi orangtua untuk terlibat di semua tingkatan proses

Berikuti ini beberapa level keterlibatan orang tua; level 1: keterlibatan orang tua, pada tingkat ini kegiatan yang melibatkan orang tua sebagai penyedia layanan. level 2, adalah tingkat orang tua terlibat sebagai sumber layanan, level 3, pada tingkat ini orang tua terlibat sebagai guru dan pembantu, level 4, ditingkat ini orang tua sebagai pengambilkeputusan, level 5, pada tingkat ini orang tua berperan sebagai pendukung dan pelobi (Morrison, 1988: 326).

Program pelibatan orang tua dapat diterapkan dengan berbagai model, . metode dan pendekatan pembelajaran. Di TK hal tersebut sangat memungkinkan untuk dilaksanakan. Sudah sejak lama prinsip-prinsip pelaksanaan pelibatan orang tua murid di TK tidak bisa terlepas dari campur tangan orang tua sebagai individu yang paling dekat dengan anak.

Menurut Morrison (1988: 323), tingkat kesiapan lembaga TK dalam hal ini guru pada program pelibatan orang tua terbagi sebagai berikut; level 1, keterlibatan orangtua dalam pada level ini mempengaruhi kesiapan pendidik dalam bersikap dan mengembangkan kemampuanya, level 2, kesiapan orang tua yang berhubungan dengan kesiapan program.

Dengan pengertian bahwa pelibatan orangtua murid di TK merupakan proses yang berkembang, sehingga program pelibatan orang tua yang akan dilaksanakan TK perlu melihat berbagai kesiapan ( kesiapan anak- anak, orang tua murid dan kesiapan lembaga TK itu sendiri ). Perlu melakukan pendekatan, sosialisasi, komunikasi dan perbaikan agar program pelibatan orang tua difahami oleh pihak-pihak terkait, yaitu anak didik, lembaga TK dan orang tua, supaya memiliki kesamaan cara pandang dan kesamaan tujuan terhadap program pelibatan orang tua yang sudah direncanakan seperti telah dikemukakan diatas Program pelibatan orang tua di pengaruhi oleh 3 hal yaitu : kesiapan program kegiatan itu sendiri, kesiapan individu orang tua murid yang akan terlibat dan kesiapan perkembangan anak didik di lembaga tersebut. 
Tujuan penelitian adalah meningkatkan perhatian, keterlibatan dan kesinambungan pendidikan orang tua, sekolah, dan lingkungan, meningkatkan kesimambungan (tidak terputus) antara program pendidikan yang dilakukan guru di TK dengan pendidikan yang dilakukan oleh orang tua dirumah, program kegiatan ngamen bareng berorientasi pada aspek perkembangan seni dan motorik anak usia dini.

Salah satu program pelibatan orang tua murid yang diteliti oleh penulis adalah pelibatan orang tua melalui kegiatan ngamen bareng yang dilaksanakan di lembaga PAUD TK Nurul Amanah Cianjur, dimana program pelibatan orang tua menekankan hubungan harmonis antara perkembangan anak-anak, kesiapan pendidik/guru dan kesiapan dukungan keluarga anak didik

Dalam proses pelaksanaan ngamen bareng di TK Nurul Amanah pelibatan orang tua ngamen bareng ini, pendidik berperan sebagai pelaksana, fasilitator , motivator dan pengendali , anak- anak berperan sebagai objek dan subjek program , pemberi inspirasi , pendorong semangat guru dan orang tua murid untuk lebih baik dalam melayani perkembangan mereka. Sementara orang tua berperan sebagai penyedia layanan kegiatan, sebagai pelaksana, pendukung dan pelobi.

Kerjasama terwujud oleh tiga komponen yang terlibat dalam kegiatan ngamen bareng yaitu guru, anak dan orang tua, masa keemasan anak akan berkembang secara optimal .Pelibatan orang tua melalui kegiatan ngamen bareng sejalan dengan prinsip yang diusulkan oleh Konstelnik (1999: 34), dengan konsep "three education" antara anak, guru dan orang tua.

Anak memiliki hak untuk ikut aktif berpartisipasi dalam membangun identitas dirinya, menunjukan gaya dana cara belajarnya, memiliki otonomi untuk mengembangkan kemampuan yang dimiliki. Orangtua sendiri memiliki hak ikut aktif dan bebas merancang untuk melibatkan orang tua, kebutuhan anak dalam pengembangan masa depan dan pertumbuhan akan terpenuhi. Demikian juga pendidik, memiliki kontribusi dalam menyusun konten, tujuan dan kegiatan pembelajaran disekolah. Komponen guru, orang tua dan anak memiliki hak yang sama dalam program pelibatan ini dan sekolah memberikan kesempatan kepada orangtua untuk berpastisipasi aktif.

Dalam pelaksanaan kegiatan ngamen bareng menerapkan peran keluarga dan masyarakat pun menjadi perhatian. Keluarga dipersilahkan berperan aktif, bekerja sama dengan guru dalam hal keterkaitan kurikulum dengan kegiatan ngamen bareng . keluarga dipersilahkan bertanya mengenai isi ketrampilan dan pengetahuan apa saja yang diperoleh anak melalui kegiatan tersebut , administrasi dan perijinan kegiatan ngamen bareng, tehnik ngamen bareng dan keputusan administratif yang harus disepakati saat pelakanaan ngamen bareng.

Konsep kerjasama dalam kegiatan ngamen bareng di TK Nurul Amanah telah melibatkan orang tua aktif secara langsung. Kegiatan ngamen bareng tidak untuk kepentingan sekolah dan bukan pula untuk kepentingan orang tua, namun lebih dari itu secara langsung dirasakan bagi kepentingan perkembangan anak anak, memberi makna langsung dalam perkembangan psikhis dan fisik motorik anak.

\section{METODOLOGI PENELITIAN}

Jenis penelitian yang dipergunakan adalah penelitian dengan metode survey. Survey dalam kegiatan ngamen bareng dilakukan untuk mengetahui keterlibatan dan pendampingan orang tua, dilakukan terhadap orang tua murid, terhadap perencanaan program kegiatan ngamen bareng TK Nurul Amanah dan terhadap lingkungan yaitu dengan menganalisa respon masyarakat disekitar TK Nurul Amanah yang secara langsung terdampak oleh kegiatan ngamen bareng. Jenis data dan analisis 
menggunakan penelitian kualitatif yaitu penelitian yang datanya adalah data kualitatif sehingga analisisnya juga analisis data kualitatif (deskriptif), yaitu data dalam bentuk kata, kalimat, dan gambar. Metode penelitian dengan tehnik observasi, wawancara, dan dokumentasi

\section{HASIL DAN PEMBAHASAN}

Pelibatan orang tua melalui kegiatan ngamen bareng menunjukkan peran serta aktif orang tua. Hal tersebut terjadi dalam musyawarah pengambilan keputusan sebelum proses pelaksanaan ngamen bersama di TK Nurul Amanah dilakanakan, yaitu; (a) orang tua membuat aturan dan tatacara ngamen besama dan memberikan sumbang saran mengenai tempat ngamen bareng yang nyaman dan aman serta banyak pengunjungnya yang nonton acara ngamen bersama tersebut, (b) orang tua membuat aturan tentang pakaian ngamen bareng, lagu yang akan dibawakan saat ngamen bareng , sampai kepada terlibat sebagai penabuh instrumen drum band saat ngamen bareng dilaksanakan orang tua terlibat secara harmonis, (c) rang tua merasa memiliki kewajiban untuk menjelaskan kepada setiap anaknya dan orang tua lain informasi tentang alur dan skenario ngamen bareng, pada saat yang sama orang tua juga memiliki pemahaman dan kesadaran tentang perbedaan perkembangan setiap anak satu sama lain, (d) komitmen orang tua dan pendidik tentang keterlibatan dalam program ngamen bareng ini dapat membantu anak untuk tumbuh dengan maksimal, karena perkembangan anak usia dini, yang didukung oleh lingkungan pembelajaran yang baik akan menjadi faktor yang paling berpengaruh dalam tumbuh kembang anak, (e) keluarga sebagai lingkungan terkecil untuk anak-anak memberikan pengaruh yang cukup besar untuk perkembangan, keluarga lah yang paling dekat dengan anak, terutama ayah dan ibu meraka menjadi individu yang akan menjadi model pertama dan utama bagi anakanak, (f) perlakuan dari orang tua kepada anak-anaknya saat pelaksanaan ngamen bareng menunjukan adanya kesinambungan program pendidikan di sekolah dan pendidikan di rumah akan membentuk kepribadian anak .

Kerjasama yang terjalin harmonis antara orang tua dan pendidik, antara pendidik dan anak didik, antara lembaga TK dan lingungan disekitar lembaga TK Nurul Amanah akan memaksimalkan semua aspek perkembangan anak secara holistik dan integratif meliputi rasa aman, terlindungi, membangun citra diri dan konsep diri yang positif, dari kegiatan ngamen bareng secara langsung anak dan orang tua diajarkan bagaimana bekerjasama dalam tim work, disiplin, belajar menghargai orng lain dan belajar meraih prestasi lewat unjuk performa.

Manfaat yang baik. Secara umum manfaat dari pelibatan orang tua dengan kegiatan ngamen bareng adalah; (1) orang tua dapat menciptakan lingkungan rumah yang dapat mendorong motivasi positif bagi anak, (b) orang tua dapat menunjukkan harapan yang tinggi (tapi masuk akal) untuk pemahaman dan masa depan anak.

Di TK Nurul Amanah pelibatan orang tua melalui kegiatan ngamen bareng yang direncanakan secara efektif dan diterapkan dengan baik telah memberi manfaat yang sangat banyak bagi orang tua, pendidik, dan sekolah. Manfaat kegiatan ngamen bareng dirasakan oleh anak, orang tua dan pendidik.

Manfaat bagi anak-anak adalah; (1) lebih paham, tanpa memandang latar belakang suku atau ras, status sosial ekonomi maupun tingkat pendidikan orang tua, (2) mendapatkan nilai unjuk kerja dan presentasi kehadiran yang lebih baik, (3) secara konsisten mengerjakan tugas tugas yang diberikan kepada mereka dengan tuntas dan tanpa paksaan, (4) memiliki harga diri yang lebih baik akan lebih disiplin dan menampakkan pendapat serta motivasi untuk bersekolah (5) perilaku positif anak-anak tentang sekolah akan selalu berhasil meningkatkan perilaku baik di sekolah serta 
mengurangi pelanggaran disiplin (6) anak-anak dari beragam latar belakang budaya mudah berbaur saat orang tua dan guru sebagai pegawai profesional bekerja sama untuk menjembatani batas antara budaya di rumah dan budaya di sekolah.

Sedangkan bagi orang tua manfaat yang didapatkan adalah; (1) meningkatkan interaksi dan diskusi dengan anak-anak mereka, (2) menjadi lebih responsiv dan sensitiv terhadap perkembangan intelektual, sosial, dan emosi anak-anak, (3) lebih percaya diri dalam mengasuh dan terampil dalam membuat keputusan, (4) memperoleh wawasan tentang perkembangan anak, akan lebih berguna dan menjadi dorong positif sehingga mengurangi pemberian hukuman pada anak-anak mereka, (5) ara orang tua memiliki pemahaman yang lebih baik tentang tugas guru dan kurikulum sekolah, (6) saat para orang tua sadar tentang apa yang dipelajari anak-anak, mereka dengan senang hati membantu ketika para guru meminta mereka terlibat dalam aktivitas pembelajaran di rumah maupun aktifitas di lembaga PAUD, (7) persepsi orang tua terhadap lembaga PAUD menjadi lebih baik dan memperkuat ikatan serta komitmen dengan sekolah, (8) lebih sadar dan menjadi lebih peduli terhadap kebijakan-kebijakan pendikdikan anakanak mereka ketika para orang tua diminta untuk terlibat sebagai tim pengambil keputusan, (9) upaya lembaga TK Nurul Amanah menyambungkan antara pendidikan di lembaganya dengan pendidikan di rumah anak-didiknya terealisasi dengan cukup baik melalui kegatan ngamen bareng.

Manfaat bagi Pendidik; (1) mudah mendapat pengalaman memperoleh kewenangan yang lebih tinggi dalam suasana kebersamaan dan kekeluargaan, (2) mendapatkan penghargaan yang lebih baik untuk profesi mereka dari para orang tua, (3) peningkatan komunikasi dan hubungan antara para orang tua, guru, dan tenaga kependidikan, (4) memiliki pemahaman yang lebih baik mengenai budaya keluarga dan keberagamannya, dan mereka memberikan penghargaan yang dalam untuk kemampuan dan waktu para orang tua, (5) melaporkan peningkatan hasil kinerja mereka kepada orang tua siswa dalam bentuk deskripsi pencapaian kompetensi dasar untuk aspek perkembangan seni dan aspek perkembangan motorik anak didiknya.

Selain aspek seni dan aspek fisik motorik yang berkembang, kegiatan ngamen bareng pun dapat mengembangkan aspek-aspek perkembangan nilai agama dan moral, kognitif, bahasa dan sikap sosial yang positif .

Kegiatan ngamen bareng memberikan manfaat bagi sekolah yaitu; (1) aktif melibatkan orang tua dan masyarakat dalam program kegiatan ngamen bareng, secara langsung mudah bagi TK Nurul Amanah dalam mewujudkan reputasi yang baik di masyarakat, (2) lebih berpengalaman dalam menyusun upaya-upaya dukungan dari masyarakat, (3) mendorong dan mendukung serta melibatkan para orang tua, memunculkan respon orang tua dan keluarganya selalu bertindak lebih baik dalam upaya lembaga TK Nurul Amanah mewujudkan program PAUD dengan kualitas tinggi, berkesinambungan dengan pendidikan anak di dalam keluarga, serta berorientasi pada seluruh aspek perkembangan anak.

\section{KESIMPULAN}

Pentingnya masa awal anak-anak harus memperoleh perhatian lebih dari orang tua, sekolah, dan lingkungan. PAUD yang berkualitas tinggi akan terwujud dengan dukungan yang berkualitas tinggi pula, dukungan yang berkualitas tinggi ditandai dengan adanya keterlibatan secara aktif dari 3 komponen pendidikan yaitu; (1) keterlibatan orang tua dan masyarakat, (2) keterlibatan peserta didik, dan (3) keterlibatan lembaga PAUD. 
Program pelibatan orang tua yang sucses di pengaruhi oleh 3 hal yaitu : (1) kesiapan program pelibatan, kesiapan individu orang tua yang akan terlibat dan kesiapan perkembangan fisik serta psikhis anak didik di lembaga tersebut. Berbagai model dan metode pelibatan orang tua banyak ditawarkan oleh banyak lembaga pendidikan untuk memenuhi kebutuhan pendidikan yang bermutu bagi anak usia dini, salah satunya di TK Nurul Amanah Cianjur yaitu pelibatan orang tua murid dan keluarganya melalui kegiatan NGAMEN BARENG . Sebelum mereka (TK Nurul Amanah, guru dan orang tua siswa) merancang kegiatan pelibatan orang tua melalui NGAMEN BARENG, kegiatan tersebut perlu dipahami oleh pendidik, anak didik dan orang tua secara utuh, baik tujuan manfaat dan dampak nya bagi pertumbuhan dan perkembangan anak.

\section{DAFTAR PUSTAKA :}

Vera, Avanti. (2014). PT Remaja Rosdakarya. Sriwijaya University Learning and Education- International Conference 2014.

Sugiyono, 2009; 9) penelitian dasar .Suriasumantri (dalam Sugiyono, 2009; 9) penelitian dasar atau murni .Home PENDIDIKAN JENIS - JENIS PENELITIAN LENGKAP. .Rijal09 Penulis Rijal 09,Diterbitkan 3/08/2016.

Carol Seefelt \& Nita Barbour, 1998 ; 13, dikutip dari buku pengelolaan kegiatan pengembangan PAUD 4407/modul 1-12.UT ) .

Anita Yus, 2011: 49. Model Pendidikan Anak Usia Dini.Jakarta: Kencana

Direktorat Pendidikan Anak Dini. Dasar Pendidikan Anak Dini’ Jakarta: Departemen Pendidikan Nasional 

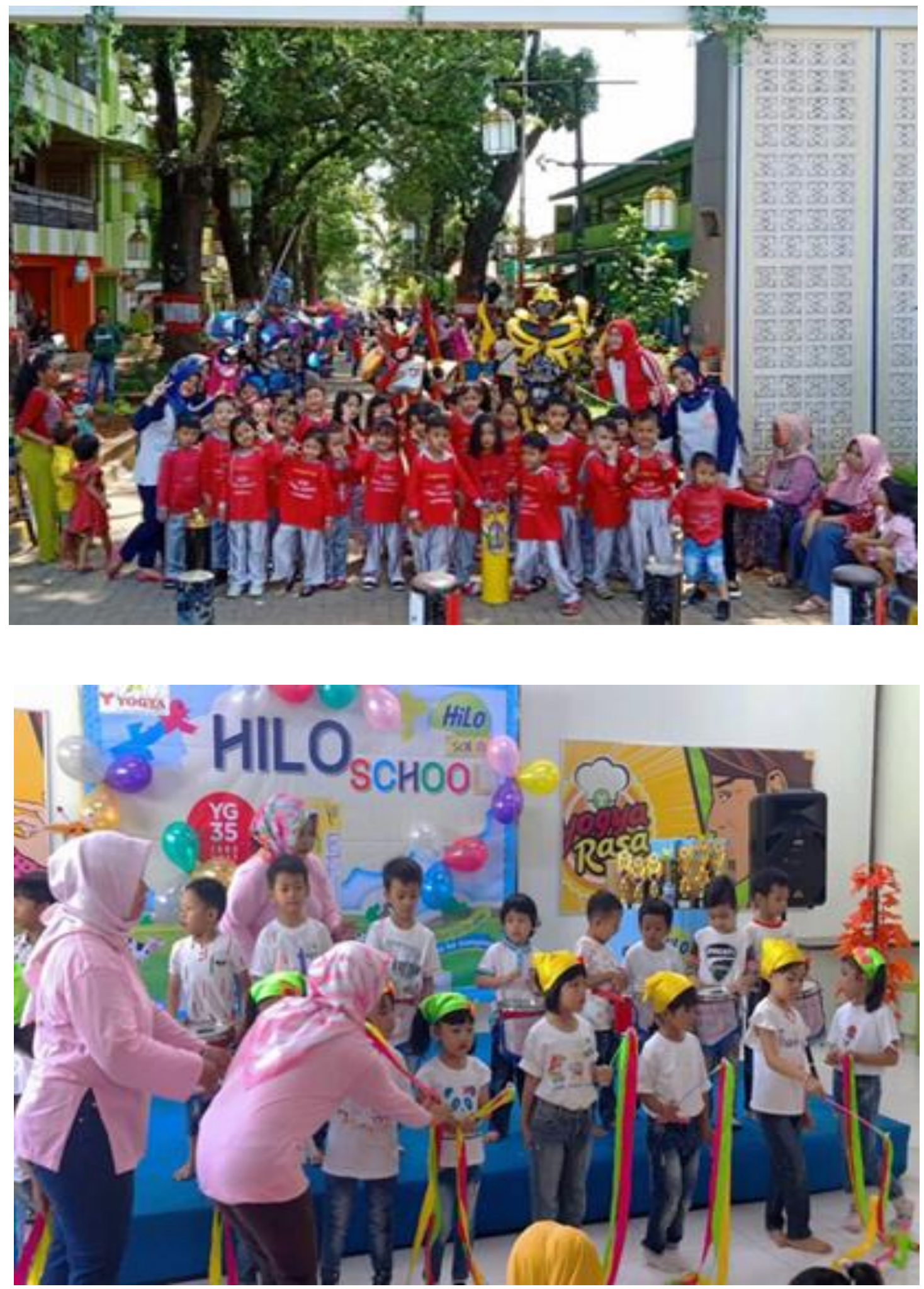

Foto Ngamen bareng tahun 2018 

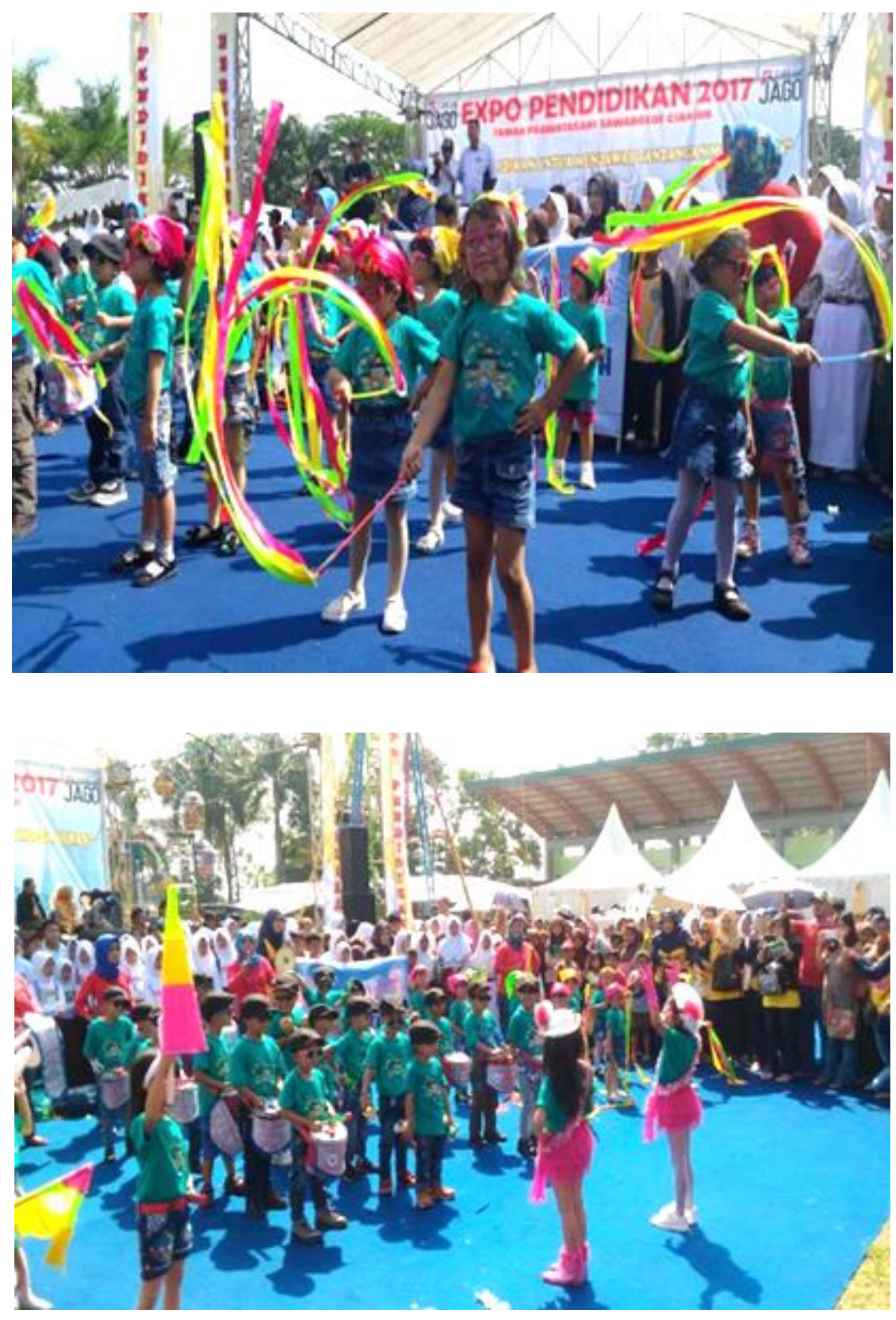

Foto Ngamen bareng tahun 2017 

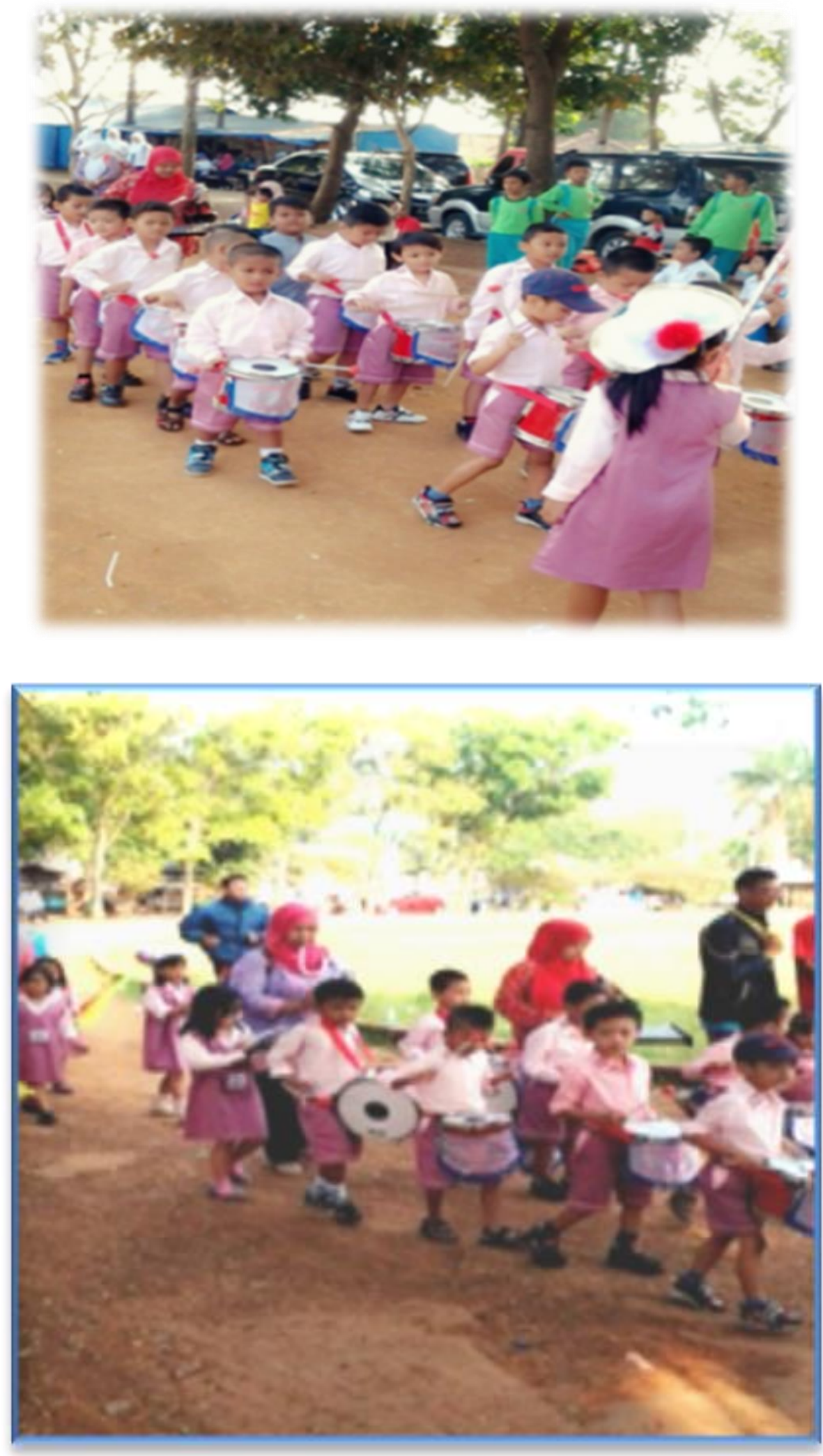

Ngamen Bareng pada Hardiknas Tahun 2015/2016 Dilapang PRAWATASARI Cianjur 